\title{
Temporal distribution of five bat species (Chiroptera, Phyllostomidae) from Panga Reserve, south-eastern Brazil
}

\author{
Wagner A. Pedro ${ }^{1}$ \\ Valdir A. Taddei ${ }^{2}$
}

\begin{abstract}
Temporal distribution of five bat species from Panga Reserve, south-eastern Brazil (Chiroptera, Phyllostomidae). Data about activity patterns, hourly and monthly, on five phyllostomid bats, Glossophaga soricina (Pallas, 1766), Anoura caudifer (E. Geoffroy, 1818), Carollia perspicillata (Linnaeus, 1758), Sturnira lilium (E. Geoffroy, 1810) and Platyrrhinus lineatus (E. Geoffroyi, 1810), studied over a one year period at the Panga Ecological Reserve, Uberlandia, Minas Gerais state, south-eastern Brazil, are reported and discussed.

KEY WORDS. Chiroptera, Phyllostomidae, temporal activity, ecological niche, migration
\end{abstract}

Some studies in ecology link differences in temporal activity patterns with niche shifts between species that are similar in ecology and morphometrics (ZARET \& Rand 1971; Kunz 1973; PianKa 1973; Marshall \& MCWILliam 1982). Other studies point out relationships between temporal activity, hourly and monthly, with food availability in phyllostomid bats (SAZIMA \& SAZIMA 1978; SAZIMA et al. 1982; LEMKE 1984; MARINHO-FILHO \& SAZIMA 1989; FISCHER 1992; FISCHER et al. 1992).

Herein, data about activity patterns, hourly and monthly, on five phyllostomid bats - Glossophaga soricina (Pallas, 1766), Anoura caudifer (E. Geoffroy, 1818), Carollia perspicillata (Linnaeus, 1758), Sturnira lilium (E. Geoffroy, 1810) and Platyrrhinus lineatus (E. Geoffroy, 1810)-studied over a one year period at the Panga Ecological Reserve, a 404 ha area South of Uberlândia, Minas Gerais State (ca. $19^{\circ} 09^{\prime}-19^{\circ} 11^{\prime} \mathrm{S} ; 48^{\circ} 23^{\prime}-48^{\circ} 24^{\prime} \mathrm{W}$ ), ca. $800 \mathrm{~m}$ altitude, are reported and discussed. The regional climate is seasonal with a five-month dry-cool season (from May to September) and a seven-month rainy hot season. The vegetation consists of $50 \%$ cerrado native scrub woodland interspersed with mesofitic forest, xeromorphic forest and grasslands.

Bats were sampled monthly with mist nets opened at sunset and closed at sunrise. Nets were checked for bats every 15 minutes. The sunset and sunrise times corresponded to data obtained from the Observatório Nacional do Rio de Janeiro, Brazil (1990, 1991). A total of 46 nights of collecting were made between June 1990 and May 1991 (ca. $552 \mathrm{~h}$ of netting). More detailed information about the collecting methods and materials are available in PEDRO \& TADDEI (1997).

1) Laboratório de Chiroptera, Departamento de Apoio, Produção e Saúde Animal, Universidade Estadual Paulista. Caixa Postal 341, 16050-680 Araçatuba, São Paulo, Brasil.

2) Universidade para o Desenvolvimento do Estado e da Região do Pantanal. 79003-010 Campo Grande, Mato Grosso do Sul, Brasil. 
Statistical analysis followed ZAR (1984), including Kolmogorov-Smirnov test, to compare the distribution of hourly activity for different species.

The frequency of capture for five Phyllostomidae species during the night are shown in figures 1 and 2 . Except for the $3^{\text {rd }}$ and $12^{\text {th }}$ hour after sunset for $G$. soricina, all five species were caught throughout the night with some differences of intensity. In order of decreasing frequency, $C$. perspicillata was captured the most frequent followed by $S$. lilium, P. lineatus, G. soricina and with $A$. caudifer the least captured. All five species had their highest rate of capture during the $1^{\text {st }}$ and $2^{\text {nd }}$ hours after sunset with a second frequency peak during the $5^{\text {th }}$ or $6^{\text {th }}$ hour, and then a slight final increase in activity during the $12^{\text {th }}$ hour just before sunrise. In general, all five species exhibited a noticeable reduction in activity during the last third of the evening from the $8^{\text {th }}$ hour to sunrise. In comparison of the two nectarivorous species (Fig. 1), Glossophaga soricina showed two activity peaks during the $1^{\text {st }}$ half of the night, and A. caudifer showed two activity peaks during the $2^{\text {nd }}$ half of the night. Glossophaga soricina was the only species not to exhibit a slight increase in capture during the $11^{\text {th }}$ hour after sunset (Fig. 1). The three frugivorous species (Fig. 2), Carollia perspicillata, S. lilium, and P. lineatus showed some similarity in hourly activity, but the primary difference was the absence of a second activity peak during the $6^{\text {th }}$ hour after sunset for $C$. perspicillata.

HEITHAus et al. (1975) were the first to suggest that temporal differences in foraging might reduce competition between some frugivorous bats, but only in the case of competition by direct interference during foraging because the fruits eaten in the beginning of the night are not replaced later in the night. Thus, frugivorous bats feeding in the beginning of the night might have a competitive advantage. Although our data show slight differences in activity patterns for the frugivorous bats, there were no obvious shifts in frequency peaks to support the idea that there was direct competition for the same food resources. The observed differences in hourly activity of frugivorous $C$. perspicillata, S. lilium and $P$. lineatus may be related to specific aspects of the biology of these species, or reflect the differences of diet as discussed in PEDRO \& TADDEI (1997): Carollia perspicillata feeds mainly on Piper, S. lilium on Solanum, and P. lineatus on Cecropia, at the Panga Ecological Reserve.

It was also suggested by HeITHAUS et al. (1975), that temporal differences in foraging may be important to the nectarivorous bats that exploit resources that are more readily renewable. MARINHO-FILHO \& SAZIMA (1989) extended this assumption to the insectivorous bats and a few studies support the hypothesis of temporal segregation in insectivorous and nectarivorous bat species (BROWN 1968; KUNZ 1973; MARSHALL \& MCWILLIAM 1982). The results presented here, although not statistically significant, show some differences in the hourly activity patterns in the nectarivorous pair-wise group of $G$. soricina-A. caudifer. However, there was no evidence from our data to suggest this because there were no obvious differences in activity patterns between the two species of nectarivorous bats.

In general the nectarivorous pair-wise species had their highest rate of capture in the beginning of the rainy season from October to December with negligible captures in the last half of the rainy season (Fig. 3). The frugivorous 

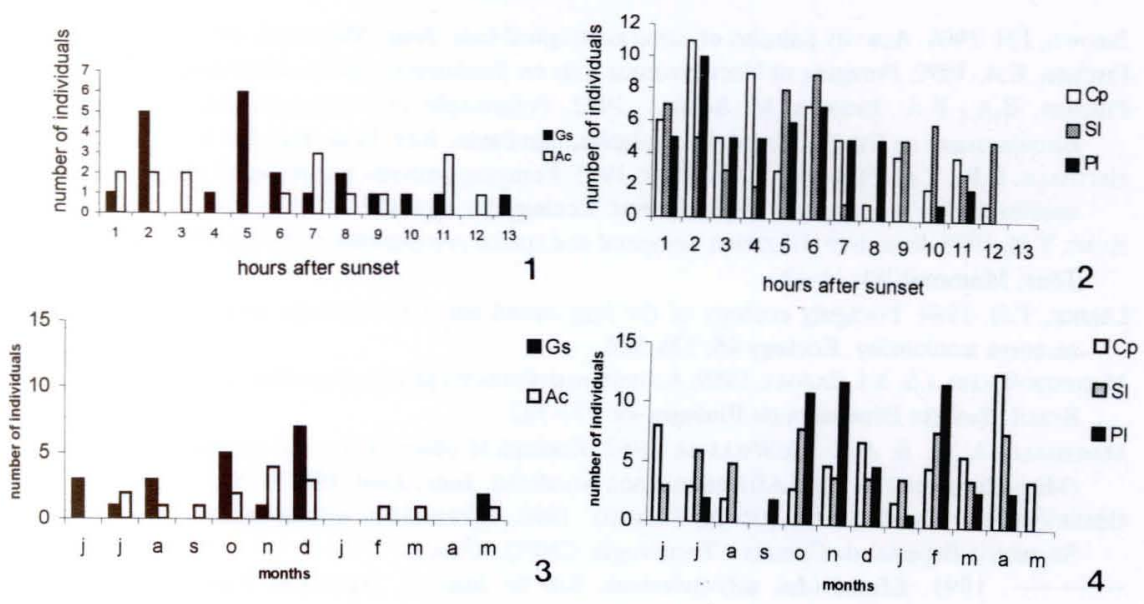

Figs 1-4. Hourly activity of Glassophaga soricina and Anoura caudifer (1) and Carollia perspicillata, Sturnira lilium and Platyrhinus lineatus (2); and frequency of captures on mist nets of Glossophaga soricina and Anoura caudifer (3) and Carollia perspicillata, Sturnira lilium and Platyrhinus lineatus (4) in the Panga Reserve.

species also exhibited their highest rates of capture in the $1^{\text {st }}$ half of the rainy season with a dramatic decrease in January before a return to higher frequencies for the last three months of the rainy season (Fig. 4). They also have a modest increase in activity near the middle of the dry season around June. There was no significant difference for the nectarivorous pair-wise species Glossophaga soricina-Anoura caudifer throughout the year (Kolmogorov-Smirnov test, $\mathrm{D}=0,154 ; \mathrm{p}>0,05$ ), or for the frugivorous pair-wise species Carollia perspicillata-Sturnira lilium (in the dry season Kolmogorov-Smirnov test, $\mathrm{D}=0,154$; $\mathrm{p}>0,05$; in the rainy season Kolmogorov-Smirnov test, $\mathrm{D}=0,077 ; \mathrm{p}>0,05$; and throughout the year Kolmogorov-Smirnov test, $\mathrm{D}=0,077 ; \mathrm{p}>0,05$ ).

The monthly activity patterns of these five Phyllostomidae species showed an increase in the rainy months when there was more food availability which bring out the opportunistic character of the foraging behavior of these bats. Monthly temporal segregation was not supported by the present data (Figs 3 and 4). The frequency of capture of frugivorous bats was, in general, highest during the rainy season (Fig. 4) suggesting the possibility of migration for at least portions of these populations in the study area, and their associations to the availability of food resources, notably Cecropia pachystachya Trec. fruits for $P$. lineatus.

ACKNOWLEDGEMENTS. We are grateful to Burton K. Lim for comments and suggestions on the manuscript, two anonymous reviewers, Paulo De Marco Jr. for help with statistics, to Carlos A.K. Komeno for help in the field, and to CNPq, CAPES and FAPESP who provided support through grants, and FUNDUNESP who provided financial support for research materials. 


\section{REFERENCES}

BRown, J.H. 1968. Activity patterns of some neotropical bats. Jour. Mammal. 49: 754-757.

FISCHER, E.A. 1992. Foraging of Nectarivorous Bats on Bauhinia ungulata. Biotropica 24: 579-582.

Fischer, E.A.; F.A. Jimenez; M. SAzima. 1992. Polinização por morcegos em duas espécies de Bombacaceae na Estação Ecológica de Juréia, São Paulo. Rev. bras. Bot. 15: 67-72.

Heithaus, E.R.; T.H. Fleming; P.A. OpLeR. 1975. Foraging patterns and resource utilization in seven species of bats in a seasonal tropical forest. Ecology 56: 841-854

Kunz, T.H. 1973. Resource utilization: temporal and spatial components of bat activity in Central Iowa. Jour. Mammal. 54: 14-32.

LEMKE, T.O. 1984. Foraging ecology of the long-nosed bat, Glossophaga soricina, with respect to resource availability. Ecology 65: 538-548.

MARINHO-FILHO, J.S. \& I. SAZIMA. 1989. Activity patterns of six phyllostomid bat species in Southeastern Brazil. Revista Brasileira de Biologia 49: 777-782.

Marshall, A. G. \& A.N. McWilliam. 1982. Ecological observations on epomophorine fruit bats (Megachiroptera) in West African savanna woodland. Jour. Zool. 198: 53-67.

ObSERVATório NACional do Rio de JANEIRO. 1990. Efemérides astronômicas. Rio de Janeiro, Secretaria Especial da Ciência e Tecnologia, CNPQ, 574p.

- 1991. Efemérides astronômicas. Rio de Janeiro, Secretaria Especial da Ciência e Tecnologia, CNPq, 574p

PEDRo, W.A. \& V.A. TADDEI. 1997. Taxonomic assemblage of bats from Panga Reserve, southeastern Brazil: abundance patterns and trophic relations in the Phyllostomidae. Bol. Mus. Biol. Mello Leitão, n. sér., Santa Teresa 6: 3-21.

PIANKA, E.C. 1973. The structure of lizard communities. Ann. Rev. Ecol. Syst. 4: 53-74.

Sazima, M.; M.E. Fabian \& I. Sazima. 1982. Polinização de Luehea speciosa (Tiliaceae) por Glossophaga soricina (Chiroptera - Phyllostomidae). Rev. Brasil. Biol. 42: 505-513.

Sazima, M. \& I. Sazima. 1978. Bat Pollination of the Passion Flower, Passiflora mucronata, in Southeastern Brazil. Biotropica 10: 100-109.

ZAR, J.H. 1984. Biostatistical Analysis. New Jersey, Prentice Hall Inc., $2^{\text {nd }}$ ed., 718p.

ZARET, T.M. \& A.S. RAND. 1971.Competition in tropical stream fishes: support for the competitive exclusion principle. Ecology 52: 336-342.

Received in 15.VI.2000; accepted in 04.IX.2002. 